\title{
THE SHEAR STRENGTH CHARACTERISTICS OF FROZEN COARSE GRANULAR DEBRIS
}

\author{
By W. G. Nigkling and L. BennetT \\ (Department of Geography, University of Guelph, Guelph, Ontario N1G 2W1, Canada)
}

\begin{abstract}
Anstract. The effect of ice content and normal load on the shear strength characteristics of a frozen coarse granular debris was investigated. 31 shear tests were carried out in a modified shearbox allowing a sample temperature of $(-1.0 \pm 0.2)^{\circ} \mathrm{C}$ and a load rate of $9.63 \times 10^{-4} \mathrm{~cm} / \mathrm{min}$. The tests showed that as the ice content of the frozen debris was increased from $0 \%$ (undersaturated) to $25 \%$ (saturated), sample shear strength was markedly increased. In contrast, sample shear strength was reduced as ice content was increased from $25 \%$ (saturated) to $100 \%$ (supersaturated). The changes in shear strength with increasing ice content were attributed directly to changes in internal friction and the cohesive effects of the pore ice. The shear tests also indicate that shear strength increases with increasing normal load up to a critical limit. Above this limit, dilatancy is suppressed causing the shear strength to decrease or remain relatively constant with increased normal load.

The stress-strain curves of the 31 tests indicated that samples with higher ice contents tended to reach peak strength $\left(\tau_{p}\right)$ with less displacement during shear. Moreover, the difference between $\tau_{\mathrm{p}}$ and $\tau_{\mathrm{r}}$ (residual strength) was lowest for pure polycrystalline ice and highest for ice-saturated samples. The Mohr-Coulomb failure envelopes displayed very distinctive parabolic curvilinearity. The degree of curvature is thought to be a function of ice creep at low normal loads and particle fracture and crushing at high normal loads.
\end{abstract}

RÉsumé. Caractéristiques de la limite de rupture de cisaillement des débris granuleux grossiers gelés. Les effets de la quantité de glace et de la charge normale sur les caractéristiques de limite de cisaillement de débris granuleux grossiers gelés ont été examinés. 31 tests de cisaillement ont été effectués dans une boite de cisaillement modifiée permettant une température de $(-1,0$ $\pm 0,2)^{\circ} \mathrm{C}$ et une vitesse de déformation de $9,63 \times 10^{-4} \mathrm{~cm} / \mathrm{min}$. Les tests ont montré qu'avec la croissance de la quantité de glace dans les débris gelés de $0 \%$ (sous-saturation) à $25 \%$ (saturation), la limite de cisaillement était nettement accrue. A l'inverse, la limite de cisaillement diminuait avec l'augmentation de la quantité de glace de $25 \%$ (saturation) à $100 \%$ (sursaturation). Les changements de la limite de cisaillement avec l'augmentation de la teneur en glace ont été attribués directement aux modification du frottement interne et aux effets sur la cohésion de la glace poreuse. Les essais de cisaillement indiquent aussi qu'avec l'augmentation de la charge normale la limite de cisaillement est portée à une limite critique. Au-delà de

\section{INTRODUCTION}

Over the past decade there has been a growing interest in the rheology of frozen soils in both North America and the Soviet Union. Much of this interest, especially in North America, has stemmed from pipeline development where detailed information is required on the aggradation and degradation of permafrost and its effect on the deformation and flow of soils (McRoberts and Morgenstern, 1977). Although a great deal of the literature on the rheology of frozen soils is primarily the product of pipeline and building-construction research, it has direct application to the deformation and flow characteristics of many natural geomorphological features such as: (1) the cutting of frozen embankments by water, (2) the loading and shearing of basal ice glacier debris, (3) talus slopes, and (4) morphology and mechanics of rock-glacier flow.

A considerable amount of research has also been carried out on the strength characteristics of frozen soils, but most of this work has been 1 imited to homogeneous fine-grained sediments (e.g. Tsytovich 1959 , p. 28-79, 1973; Vyal ov and others, 1962, 1966; cette limite la dilatation durant le cisaillement est supprimée ce qui entraîne une diminution ou un maintien relativement constant de la limite de cisaillement quand la charge normale croît.

Les courbes contraintes-déformation des 31 tests indiquent que les échantillons de plus grandes teneurs en glace tendent à atteindre un pic de résistance $\left(\tau_{p}\right)$ avec un moindre taux de déformation. De plus, la différence

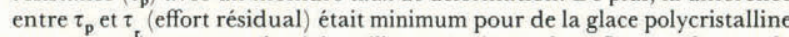
pure et maximum pour les échantillons saturés en glace. Les enveloppes de rupture de Mohr-Coulomb montraient de très distinctes lignes courbes paraboliques. On pense que le degré de courbure doit être une fonction des fractures et écrasements des particules aux charges normales élevées.

Zusammenfassung. Die Charakteristiken der Scherfestigkeit gefrorenen, grobkörnigen Schuttes. Die Wirkung von Eisgehalt une Normal-Last auf die Charakteristiken der Scherfestigkeit eines gefrorenen, grobkörnigen Schuttes wurde untersucht. Mit einem modifizierten Schergehäuse, das eine Probentemperatur von $(-1,0 \pm 0,2)^{\circ} \mathrm{C}$ und eine Belastungsrate von $9,63 \times 10^{-4} \mathrm{~cm}$ pro min zulässt, wurden 31 Scherversuche vorgenommen. Die Versuche zeigten, dass mit einer Zunahme des Eisgehaltes in dem gefrorenen Schutt von $0 \%$ (ungesättigt) auf 25\% (gesättigt) die Scherfestigkeit der Probe wesentlich anstieg. Im Gegensatz dazu nahm die Scherfestigkeit ab, wenn der Eisgehalt von $25 \%$ (gesättigt) auf $100 \%$ (übersättigt) gesteigert wurde. Die Anderungen der Scherfestigkeit bei zunehmendem Eisgehalt wurden direkt der inneren Reibung und den Kohäsionswirkungen im Poreneis zugeschrieben. Die Scherversuche ergaben ausserdem, dass mit einer Zunahme der Normal-Last die Scherfestigkeit auf einen kritischen Grenzwert ansteigt. Úber diesem Grenzwert wird die Ausdehnung unterdrückt, was eine Abnahme oder relative Konstanz der Scherfestigkeit bei zunehmender Normal-Last zur Folge hat.

Die Spannungskurven der 31 Versuche zeigten, dass Proben mit höherem Eisgehalt dazu neigten, ihre höchste Festigkeit $\left(\tau_{p}\right)$ bei geringerer Verlagerung während der Scherung zu erreichen. Des weiteren war die Differenz zwischen $\tau_{\mathrm{p}}$ und $\tau_{\mathrm{r}}$ (Restfestigkeit) am niedrigsten für reines, polykristallines Eis und am höchsten für eisgesättigte Proben. Die Mohr-Coulomb'schen Bruchhüllkurven zeigten sehr unterschiedliche parabolịsche Krümmungslinearität. Der Grad der Krümmung wird als Funktion des Eiskriechens bei geringer Normal-Last und der Aufspaltung und Zerquetschung von Partikeln bei hoher Normal-Last angenommen.

Goughnor and Andersland, 1968; Sayles, 1973). The more complex mixtures of gravels, sands, silts, and/ or clays have not been the subject of detailed studies. Information on the rheology of these heterogeneous coarse-grained materials is necessary for detailed investigation of the morphology and flow characteristics of such features as talus cones and rock glaciers common to alpine environments.

As a result of this lack of background information, a laboratory investigation of the strength characteristics of frozen coarse-grained sediments was undertaken. This work formed part of an overall project investigating the morphology and flow characteristics of rock glaciers in Grizzly Creek Valley, Yukon Territory (Johnson, 1978).

The basic objective of this work was to determine the relationship between peak strength and ice content under differing normal loads and constant temperature for coarse-grained matrix debris. The coarsegrained material used in the experiments was derived from two active rock glaciers located in Grizzly Creek Valley. 


\section{THE STRENGTH OF FROZEN GRANULAR SOILS}

The strength envelope of unfrozen granular soils may be determined with reasonable accuracy by means of the Mohr-Coulomb equation

$$
S=c+\sigma_{n} \tan \phi
$$

where $c$ is cohesion, $\sigma_{n}$ is normal load, and $\phi$ the angle of internal friction. This equation is also suitable for certain frozen soils under specific conditions. However, the accuracy of the equation is significantly affected by ice content and temperature (Vyalov and others, 1966).

Sayles (1973) suggests that the linear MohrCoulomb equation may be used to describe the strength characteristics of frozen sands with low ice contents and porosities of less than $37 \%$. Beyond these limits, the strength curves are not linear, but parabolic (Ladanyi, 1972).

Shusherina and Bobkov (1969) have shown that the strength of frozen fine-grained soils, under constant normal load, strain-rate, and temperature, increases with increasing ice content until reaching a threshold whereafter the strength decreases to some limit. This threshold corresponds to the point where the ice content of the sample is just sufficient to fill the available void space. As ice content increases beyond this threshold, a point is reached when the strength of the frozen sample becomes more dependent on the strength of the ice than the strength of the soilgrain matrix. This point, termed the critical ice content, is indicated by a distinct break of slope on the plot of peak strength against ice content (Goughnor and Andersland, 1968).

Temperature and strain-rate can also have a significant effect on the peak strength of frozen soils (Tsytovich, 1973; Andersland and Al Nouri, 1970). For example, as soil temperature decreases, unfrozen water content decreases, which increases the soil strength. Ladanyi (1972) suggests that the increasing viscosity of ice (which is a product of lower temperatures), results in greater bond strengths. Tsytovich

(1973) notes that as the temperature of a medium sand changes form $-1.0^{\circ} \mathrm{C}$ to $-2.0^{\circ} \mathrm{C}$, the compressive strength of this material increases by $15 \%$. He also suggests that under the same moisture conditions the compressive strength of a clay would increase by $50 \%$.

As is the case with unfrozen soils, increased strain-rate results in increased peak strength. Alternatively, if a frozen sample is subjected to a low strain-rate internal bonds are weakened and internal resistance reduced resulting in deformation (Tsytovich, 1959). In such cases ice crystals may shift, shear parallel to basal planes, or be destroyed. The stresses caused by shifting soil grains may promote pressure-melting of the ice and refreezing in an area of lower pressure. The re-formed ice crystals are generally smaller, and have a preferred orientation to allow dissipation of planar stresses.

The transfer of water in this manner provides the opportunity for granular adjustment or soil creep. Creep occurs when gravity-induced shear stresses are of sufficient magnitude to cause deformation, but are not of sufficient magnitude to induce shear failure. The continuing creep of the frozen soil depends upon two factors: changing cohesion (c) and changing angle of internal friction $(\phi)$. As the ice content is reduced in areas of stress, soil particles are placed in closer contact. Thus $\phi$ is increased and molecular cohesion is increased. The reduction in porosity increases structural cohesion. If the strengthening process (particle rearrangement and bond creation) exceeds the weakening process (ice reorientation and bond creation), then soil creep is damped. If the applied stress is of a sufficient magnitude to exceed the long-term strength of the frozen debris, visco-plastic creep results, which may lead to progressive flow and shear failure (Chamberlain and others, 1972).

\section{METHODOLOGY}

Bulk sample preparation

Two bulk samples of approximately $40 \mathrm{~kg}$ each were obtained from two active valley-side rock glaciers located in Grizzly Creek, Yukon Territory (Johnson, 1978). The samples were retrieved from the bottoms of trenches cut into active lobes of the rock glaciers. The samples were collected at depths of $2.50 \mathrm{~m}$ and $2.25 \mathrm{~m}$ and had in situ ice contents of approximately $45 \%$ and $65 \%$ respectively. Grain-size analysis of the bulk samples showed that the material from the two rock glaciers were similar in textural characteristics and had means of $-2.90 \phi(7.5 \mathrm{~mm})$ and $-3.00 \phi$ $(8.0 \mathrm{~mm})$ (Fig. 1).

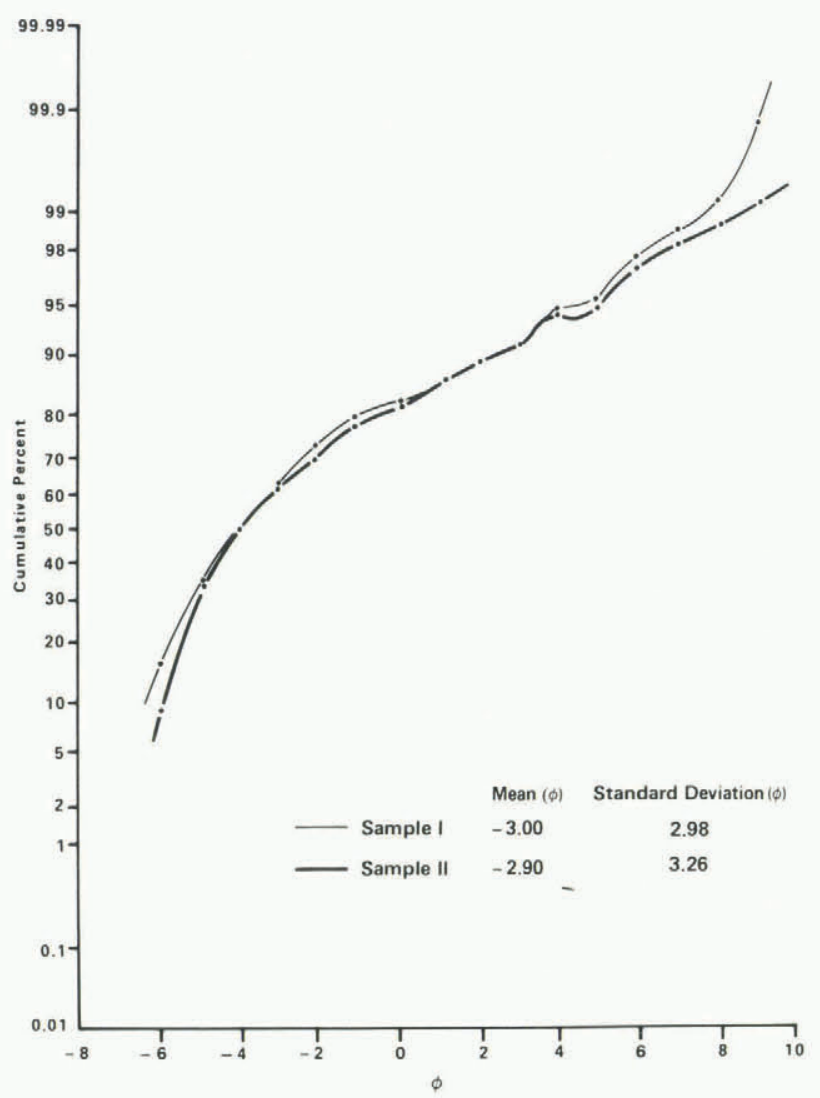

Fig. 1. Typical grain-size distributions of the test samples.

Approximately $25 \%$ of each sample consisted of particles greater than $4 \mathrm{~cm}(-5.3 \phi)$, which is larger than the maximum particle size that can be tested in the $30.5 \mathrm{~cm} \times 30.5 \mathrm{~cm}$ shearbox used in the study. Carson and Petley (1970) suggest that if cobbles or rocks are simply resting in a matrix of fines, then they have no bearing upon the ultimate strength of the material. Thus, the replacement of coarse materials with finer materials does not affect the strength characteristics of the matrix. All particles in the rock glacier matrix greater than $-5.3 \phi$ were removed and replaced by an equal volume of materials of the maximum size that could be used in the shearbox $(-5.3 \phi)$.

\section{Shearbox preparation}

A standard $30.48 \mathrm{~cm} \times 30.48 \mathrm{~cm}$ (12 inch $\times 12$ inch) Waykem-Farrance direct-drive shearbox was used for the study, with the addition of a freezing chamber (Kavalak, unpublished) to facilitate the testing of frozen samples (Fig. 2). The freezing chamber was constructed of fir plywood $1.6 \mathrm{~cm}$ thick covered with 
ELECTRONIC CONTROL UNIT
$30 \mathrm{~cm}$

SHEAR BOX
REMOVABLE FREEZING APPARATUS

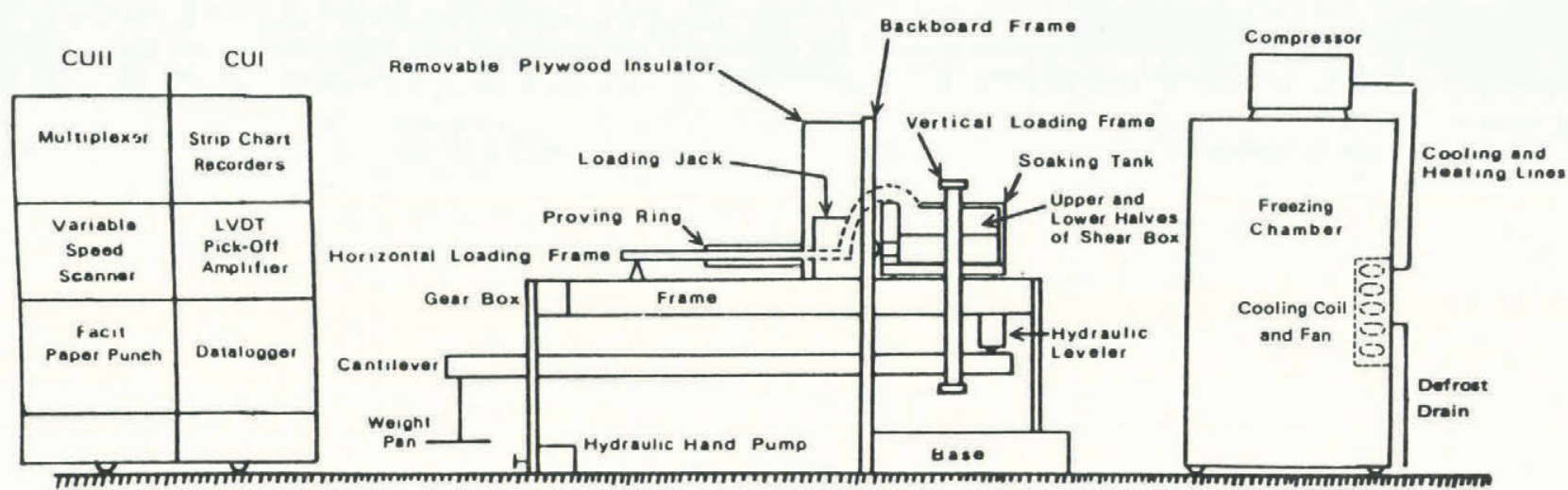

Fig. 2. Schematic diagram of shearbox and freezing chamber.

a $10 \mathrm{~cm}$ thickness of rigid styrofoam (expanded polystyrene). In addition, a $0.3 \mathrm{~cm}$ thick hardboard protective cover was glued over the styrofoam. The chamber was mounted on casters enabling it to be moved into place against a rigid insulated plywood backboard that separated the loading frame and shearbox from the rest of the machine (Fig. 2). The chamber was fixed in position to the backboard by means of spring-l oaded clamps.

Two narrow slots for the horizontal rods and a circular hole for the cantilever were cut through the backboard and the air gaps sealed with flexible neoprene rubber. A small detachable insulated plywood cover was also constructed to fit over the entire loading-jack housing. Narrow slots were cut through the cover to allow the passage of the horizontal loading-frame rods.

Temperature $\left(0^{\circ} \mathrm{C}\right.$ to $\left.(-18 \pm 0.2)^{\circ} \mathrm{C}\right)$ inside the freezing chamber was controlled by a compressor unit mounted directly on top of the chamber. The cooling coils for the compressor and two small circulation fans were fastened to the inside back wall of the freezing chamber.

In addition to the above modifications the shearbox was also re-geared to obtain a load rate of $9.63 \times$ $10^{-4} \mathrm{~cm} / \mathrm{min}$ to approximate more closely to the rates of deformation found in field studies of rock-glacier movement (Whalley, 1974).

Although all shear tests were conducted following standard testing procedures (Akroyd, 1957), special preparatory procedures were required for the frozen samples. In order to prepare the test samples at specific ice contents, known quantities of finely crushed ice and distilled water were added to the sample in the shearbox. Since the shearbox frame was not waterproof, it was necessary to seal the lower half of the shearbox frame to the water reservoir with silicon sealant. The most efficient seal at the shearplane proved to be a leather gasket coated on both sides with petrolatum. The loading plate was also sealed to the upper half of the shearbox with a thick layer of petrolatum to prevent sample evaporation during the three minute defrost cycles of the freezing chamber.

To prevent the sample from freezing to the metal shearbox frame, the shearbox was lined with a multilayer system composed of a thin layer of petrolatum, $4 \mathrm{mil}$ polyethylene sheeting, and aluminum foil. With the multilayer liner in place, 95 to $100 \%$ of each sample could be removed as a single frozen block for further inspection.

It was not known how the multilayer liner would affect the shear strength of the tested samples. Thus, twelve tests were undertaken using coarse and fine sands. With the multilayer in place, tested samples showed a very minor increase in shear strength. This was most noticeable at high normal loads. At low normal loads, the multilayer shifted in response to shearing while at high normal loads it was torn apart at the shear plane. Since the multilayer reacted in the same manner during the frozen tests, it was assumed to have the same effects on the matrix. The effects of the shearbox lining were subtracted from the final test results.

\section{Testing procedure}

The samples were prepared for shear testing in a similar manner to that described by Vyalov and others (1966) for frozen sands. During each sample preparation an attempt was made to ensure an ice-saturated condition at a given void ratio. Knowing the volume of the shear box and the densities of the mineral grains and ice, the volume of ice required to saturate the sample at the test void ratio (ice content) was calculated. Approximately $80 \%$ of the required volume of water for ice-saturation in the sample was frozen $\left(-10^{\circ} \mathrm{C}\right)$ and thoroughly crushed to a fine powder. The finely crushed ice was then mixed with a predetermined volume of rock-glacier material $\left(-10^{\circ} \mathrm{C}\right)$ and packed into the pre-chilled shearbox. After thermocouples had been installed into the sample and the sample levelled to the shearing frame the remaining volume of distilled water $\left(+0.5^{\circ} \mathrm{C}\right)$ required for ice saturation was added uniformly to the sample surface. The chilled water entered the sample by capillarity being held within the sample fines and the pulverized ice. In most cases this resulted in the ice being partially reduced to a slurry. No attempt was made to evacuate air from the pores. However, inspection of frozen samples following preliminary tests showed that a fairly uniform ice distribution was achieved by using the above technique.

Following the addition of the distilled water, the loading frame and plate were positioned and weights added to the weight pan (Fig. 2). The freezing chamber was connected to the backboard frame and set for $-20^{\circ} \mathrm{C}$. During the cool-down, the sample was allowed to consolidate to the required void ratio as indicated by linear variable displacement transducers. Since the volume of ice required to saturate the sample at the test void ratio had been calculated, little drainage of water or extrusion of slush occurred during sample consolidation. It was not apparent during any of the sample preparations that 
the samples reached a minimum void ratio (closepacked arrangement) before the desired test void ratio was achieved. Following sample consolidation, enough weights were removed from the weight pan to stop further consolidation. The remaining weights were left in place to reduce the effects of frost heave during freezing.

When the sample reached approximately $-10^{\circ} \mathrm{C}$, the freezer was reset to $-1.0^{\circ} \mathrm{C}$ and the sample was allowed to reach equilibrium over the next $12 \mathrm{~h}$. When equilibrium had been attained, the correct normal load was applied to the weight pan and the drive rate set to $9.63 \times 10^{-4} \mathrm{~cm} / \mathrm{min}$, which approximates the measured flow rates of active rock glaciers (e.g. Whalley, 1974). The shearbox was then started and the test allowed to run for approximately $52 \mathrm{~h}$. Ambient and sample temperatures were measured every $30 \mathrm{~m}$ by five copper-constantan thermocouples and recorded on a digital recorder. Horizontal and vertical displacement of the frozen sample were continuously monitored by two linear voltage displacement transducers and recorded on two strip-chart recorders. In addition these data were stored on paper tape to allow for the transfer and storage of the shear data to the main computer facilities.

\section{Ice content determination}

Following the shear test the sample was chilled in situ to $-10^{\circ} \mathrm{C}$ to eliminate excessive melting during ice determination. The intact frozen sample was removed from the shearbox and carefully lowered into a levelled galvanized steel overflow tank which contained a pre-chilled $\left(-10^{\circ} \mathrm{C}\right)$ mixture of propanal and distilled water $(50: 50)$. The amount of overflow from the tank was carefully collected and the volume of the fluid, and hence the volume of the frozen sample, was determined.

The frozen sample was then placed in a drying oven for $24 \mathrm{~h}$ at $105^{\circ} \mathrm{C}$ and subsequently weighed. The volumetric ice content was determined by

$$
C_{I}=\frac{V_{F S}-V_{D S}}{V_{D S}} \times 100
$$

where $V_{D S}$ is the volume of the dry sample defined by $V_{D S}=W_{D S} / 2.76 \mathrm{Mg} / \mathrm{m}^{3}$, $W_{D S}$ being the weight of the dry sample, and $V_{F S}$ is the volume of the frozen sample.

\section{RESULTS}

Introduction

A total of 31 shear tests were run on the two frozen rock-glacier matrix samples for ice contents ranging from 0.00 to $63.59 \%$ (Table I). All tests were run at $(-1.0 \pm 0.2)^{\circ} \mathrm{C}$ with a loading rate of $9.63 \times$ $10^{-4} \mathrm{~cm} / \mathrm{min}$. Reproducibility of ice contents for a given test set was good with values ranging by less than $3.5 \%$ (Table I).

Al though the frozen dry samples FD1 to FD8 are indicated as having zero ice content they were not in fact totally devoid of ice because a small amount of water $(1.4-2.3 \%)$ had to be added to the sample prior to testing to ensure proper mixing of the fines. As a result these samples actually contained approximately $1.5-2.5 \%$ ice by volume (Table I). Tsytovich (1973) however, suggests that such small quantities of ice have virtually no effect on the shear-strength characteristics of coarse-grained soils. It is therefore assumed that these samples will react in a similar manner to those with zero ice content.

In addition to the frozen matrix samples, four tests were also run on pure polycrystalline ice for varying normal loads at $(-1.0 \pm 0.2)^{\circ} \mathrm{C}$.

Frozen test samples: zero ice content

The zero ice content stress-strain curves for bulk samples I and.II are shown in Figure 3, and indicate
TABLE I. THE SHEAR-TEST DATA

\begin{tabular}{|c|c|c|c|}
\hline Test number & $\begin{array}{l}\text { Normal load } \\
\mathrm{kgf} \mathrm{cm}^{2}\end{array}$ & Void ratio & $\underset{\%}{\text { Ice content }}$ \\
\hline $\begin{array}{l}\text { FD1 } \\
\text { FD2 } \\
\text { FD3 } \\
\text { FD4 } \\
\text { FD5 } \\
\text { FD6 } \\
\text { FD7 } \\
\text { FD8 }\end{array}$ & $\begin{array}{l}1.61 \\
1.61 \\
1.61 \\
1.08 \\
0.54 \\
0.54 \\
1.08 \\
1.61\end{array}$ & $\begin{array}{l}0.28 \\
0.28 \\
0.28 \\
0.28 \\
0.28 \\
0.28 \\
0.28 \\
0.28\end{array}$ & $\begin{array}{l}1.83^{\star} \\
2.04 \\
2.14 \\
2.51 \\
1.65 \\
1.56 \\
1.90 \\
1.96\end{array}$ \\
\hline $\begin{array}{l}\text { FT1 } \\
\text { FT2 } \\
\text { FT3 } \\
\text { FT16 }\end{array}$ & $\begin{array}{l}0.54 \\
1.08 \\
1.61 \\
0.30\end{array}$ & $\begin{array}{l}1.00 \\
1.00 \\
1.00 \\
1.00\end{array}$ & $\begin{array}{l}100 \\
100 \\
100 \\
100\end{array}$ \\
\hline $\begin{array}{l}\text { FT4 } \\
\text { FT5 } \\
\text { FT6 } \\
\text { FT17 }\end{array}$ & $\begin{array}{l}0.54 \\
1.08 \\
1.61 \\
0.30\end{array}$ & $\begin{array}{l}0.64 \\
0.61 \\
0.63 \\
0.60\end{array}$ & $\begin{array}{l}63.59 \\
60.50 \\
62.55 \\
60.12\end{array}$ \\
\hline $\begin{array}{l}\text { FT7 } \\
\text { FT8 } \\
\text { FT9 } \\
\text { FT18 }\end{array}$ & $\begin{array}{l}0.54 \\
1.08 \\
1.61 \\
0.30\end{array}$ & $\begin{array}{l}0.47 \\
0.46 \\
0.49 \\
0.48\end{array}$ & $\begin{array}{l}46.99 \\
46.26 \\
49.04 \\
47.66\end{array}$ \\
\hline $\begin{array}{l}\text { FT10 } \\
\text { FT11 } \\
\text { FT12 }\end{array}$ & $\begin{array}{l}0.54 \\
1.08 \\
1.61\end{array}$ & $\begin{array}{l}0.30 \\
0.31 \\
0.28\end{array}$ & $\begin{array}{l}30.06 \\
30.95 \\
27.90\end{array}$ \\
\hline $\begin{array}{l}\text { FT13 } \\
\text { FT14 } \\
\text { FT15 } \\
\text { FT19 }\end{array}$ & $\begin{array}{l}0.54 \\
1.08 \\
1.61 \\
0.30\end{array}$ & $\begin{array}{l}0.25 \\
0.25 \\
0.24 \\
0.24\end{array}$ & $\begin{array}{l}25.09 \\
25.07 \\
24.48 \\
24.42\end{array}$ \\
\hline $\begin{array}{l}\mathrm{FT} 2 / 1 \\
\mathrm{FT} 2 / 2 \\
\mathrm{FT} 2 / 3 \\
\mathrm{FT} 2 / 4\end{array}$ & $\begin{array}{l}1.61 \\
1.61 \\
1.61 \\
1.61\end{array}$ & $\begin{array}{l}0.59 \\
0.51 \\
0.31 \\
0.25\end{array}$ & $\begin{array}{l}58.87 \\
50.51 \\
30.69 \\
25.44\end{array}$ \\
\hline $\begin{array}{l}\text { IFT1 } \\
\text { IFT2 } \\
\text { IFT3 } \\
\text { IFT4 }\end{array}$ & $\begin{array}{l}1.08 \\
1.08 \\
1.08 \\
1.61\end{array}$ & $\begin{array}{l}0.53 \\
0.37 \\
0.26 \\
0.59\end{array}$ & $\begin{array}{l}53.36 \\
37.11 \\
25.58 \\
58.79\end{array}$ \\
\hline
\end{tabular}

* Ice contents of tests FD1 to FD8 are assumed to approximate zero per cent, see text.

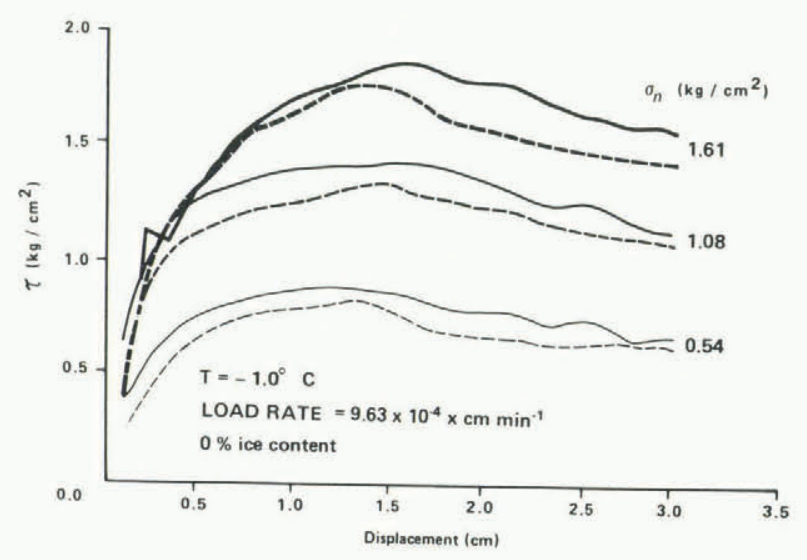

Fig. 3. $0 \%$ ice content stress-strain curves.

the similarity of strength characteristics between these two samples. In both cases peak resistance to shear occurred between 0.9 and $1.6 \mathrm{~cm}$ of displacement and was achieved sooner in those runs subject to lower normal loads. The difference between the peak and residual strength is rather small considering the 


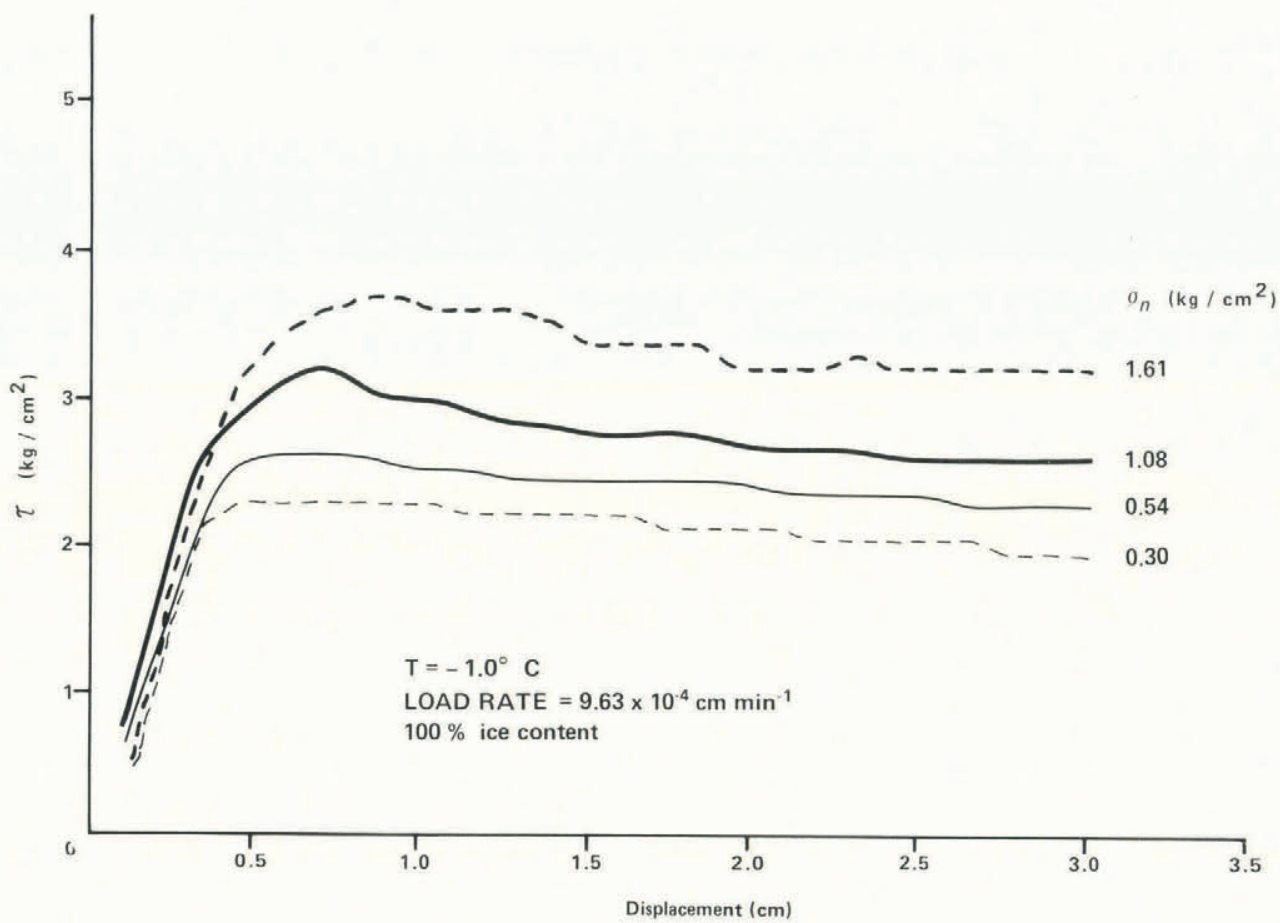

Fig. 4. Polycrystalline ice stress-strain curves.

coarse texture of the material and the relatively high normal loads.

Frozen test samples: $100 \%$ ice content (pure polycrystalline ice)

The results of the shear tests on pure polycrystalline granular ice are shown in Figure 4. Peak strength occurs between 0.5 and $0.8 \mathrm{~cm}$ of displacement followed by ultimate strength $(\tau p)$ which averages just $15 \%$ less than peak strength. The actual difference between peak strength and residual strength is a function of the sample temperature and strainrate; where the difference is significant, brittle failure occurs and where the difference is minimal a very plastic or ductile failure occurs (Gold, 1970). Since the test samples were close to pressure-melting temperatures (warmer than $-3.0^{\circ} \mathrm{C}$ ) and the rate of strain quite low, the ice most probably responded to the shear stress by ductile failure (Hobbs, 1974).

Frozen test samples: ice saturated

All FT tests (Table I) are assumed to be approximately ice saturated as a result of the method used for sample preparation. Thus it is assumed that all void space is filled with ice and consequently the void ratio (e) approximates to the ice content. It is noted, however, that it was not possible to eliminate all air space during sample preparation, but the ice condition in the samples is thought to be similar to that which would exist under natural in situ conditions in the rock glacier.

The stress-strain curves for all FT tests are given in Figure 5. Each plot presents the results of four tests on Sample I at constant temperature and ice content with increasing normal load $\left(\sigma_{n}\right)$. (N.B. in Fig. $5 c$, data for the $\sigma_{n}=0.3 \mathrm{kgf} \mathrm{cm}^{-2}, 30 \%$ ice content test are not available because of equipment failure during the sample run.)

The stress-strain curves of the saturated samples lack the smoothness or regularity of those of the polycrystalline ice samples. While the polycrystalline ice quickly reached peak strength $\left(\tau_{p}\right)$ then fell smoothly to the respective residual strengths $\left(\tau_{r}\right)$, the higher saturated samples with ice content (e.g.
$48 \%$ and $61 \%$ ) rose intermittently to peak strength then fell in an irregular manner to the residual strength. This was more clearly indicated by the detailed stripchart recorders which monitored the sample continuously, unlike the computer plots (Fig. 5) which plot data points at $2 \mathrm{~h}$ intervals.

On average, the $0 \%$ ice content samples reached peak strength after $1.4 \mathrm{~cm}$ of displacement. In com-

\section{TABLE II. STRESS-STRAIN DATA ANALYSIS SUMMARY}

\begin{tabular}{|c|c|c|c|c|c|}
\hline $\begin{array}{c}\text { Ice } \\
\text { content } \\
\%\end{array}$ & $\begin{array}{c}\text { Normal } \\
\text { load } \\
\mathrm{kgf} / \mathrm{cm}^{2}\end{array}$ & $\begin{array}{l}\text { Displacement } \\
\text { peak strength } \\
\mathrm{cm}\end{array}$ & Mean & $\tau_{r} / \tau_{p}$ & Mean \\
\hline \multirow[t]{2}{*}{100} & $\begin{array}{l}1.61 \\
1.07 \\
0.54 \\
0.30\end{array}$ & $\begin{array}{l}0.79 \\
0.69 \\
0.47 \\
0.47\end{array}$ & & $\begin{array}{l}0.870 \\
0.800 \\
0.875 \\
0.857\end{array}$ & \\
\hline & & & 0.61 & & 0.851 \\
\hline \multirow[t]{2}{*}{61} & $\begin{array}{l}1.61 \\
1.07 \\
0.54 \\
0.30\end{array}$ & $\begin{array}{l}1.04 \\
0.59 \\
0.89 \\
0.59\end{array}$ & & $\begin{array}{l}0.717 \\
0.674 \\
0.694 \\
0.781\end{array}$ & \\
\hline & & & 0.78 & & 0.717 \\
\hline \multirow[t]{2}{*}{48} & $\begin{array}{l}1.61 \\
1.07 \\
0.51 \\
0.30\end{array}$ & $\begin{array}{l}0.91 \\
0.90 \\
0.91 \\
0.69\end{array}$ & & $\begin{array}{l}0.764 \\
0.694 \\
0.769 \\
0.818\end{array}$ & \\
\hline & & & 0.95 & & 0.761 \\
\hline \multirow[t]{2}{*}{30} & $\begin{array}{l}1.61 \\
1.07 \\
0.54 \\
0.30\end{array}$ & $\begin{array}{l}0.91 \\
0.91 \\
0.83 \\
\text { N/A }\end{array}$ & & $\begin{array}{l}0.750 \\
0.768 \\
0.796 \\
\text { N/A }\end{array}$ & \\
\hline & & & 0.88 & & 0.771 \\
\hline 25 & $\begin{array}{l}1.61 \\
1.07 \\
0.54 \\
0.30\end{array}$ & $\begin{array}{l}0.99 \\
0.88 \\
0.91 \\
0.67\end{array}$ & & $\begin{array}{l}0.656 \\
0.622 \\
\text { N/A } \\
0.658\end{array}$ & \\
\hline
\end{tabular}



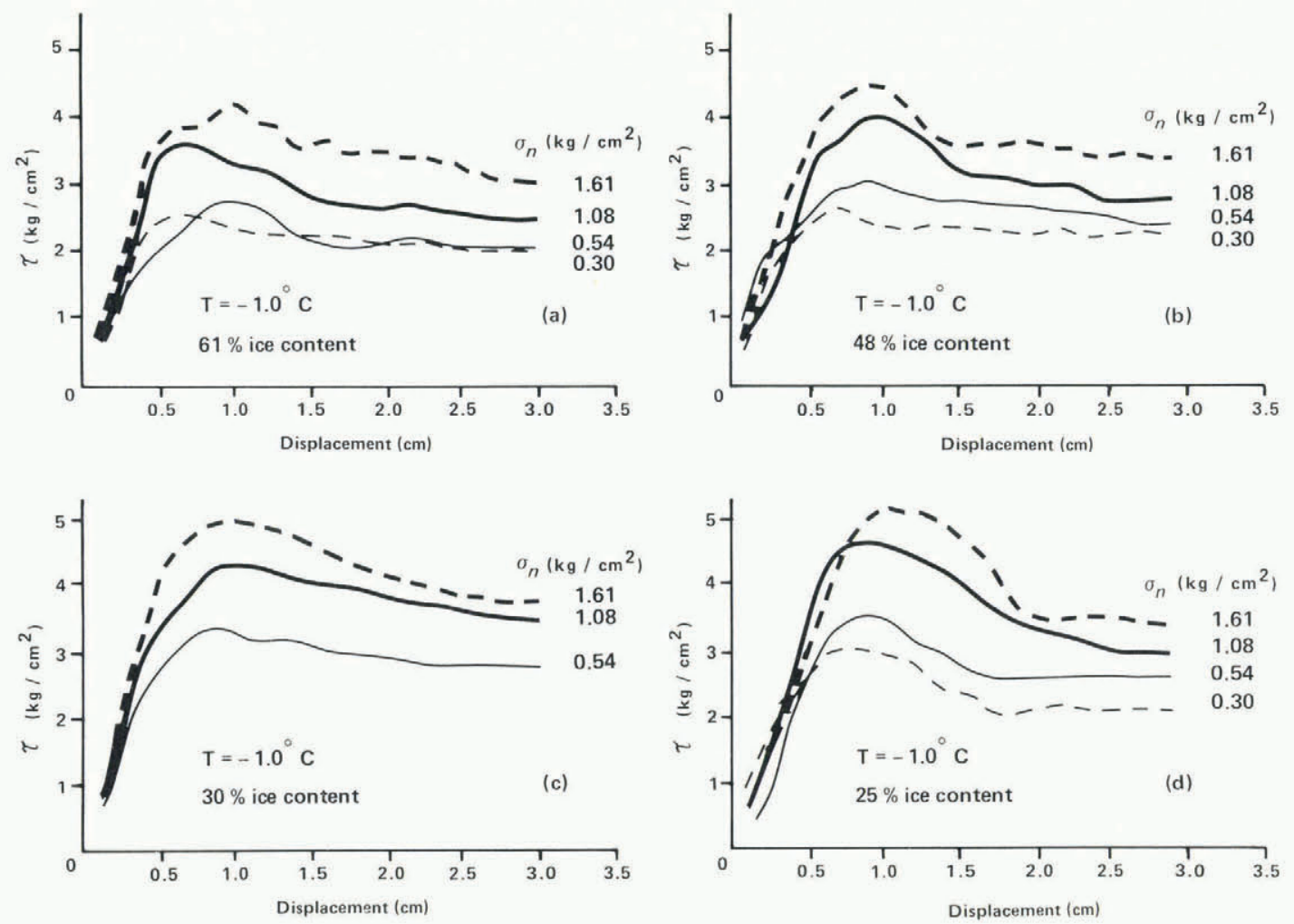

Fig. 5. Stress-strain curves of the frozen ice-saturated samples. Load rate for all tests was $9.63 \times 10^{-4} \mathrm{~cm} / \mathrm{min}$.

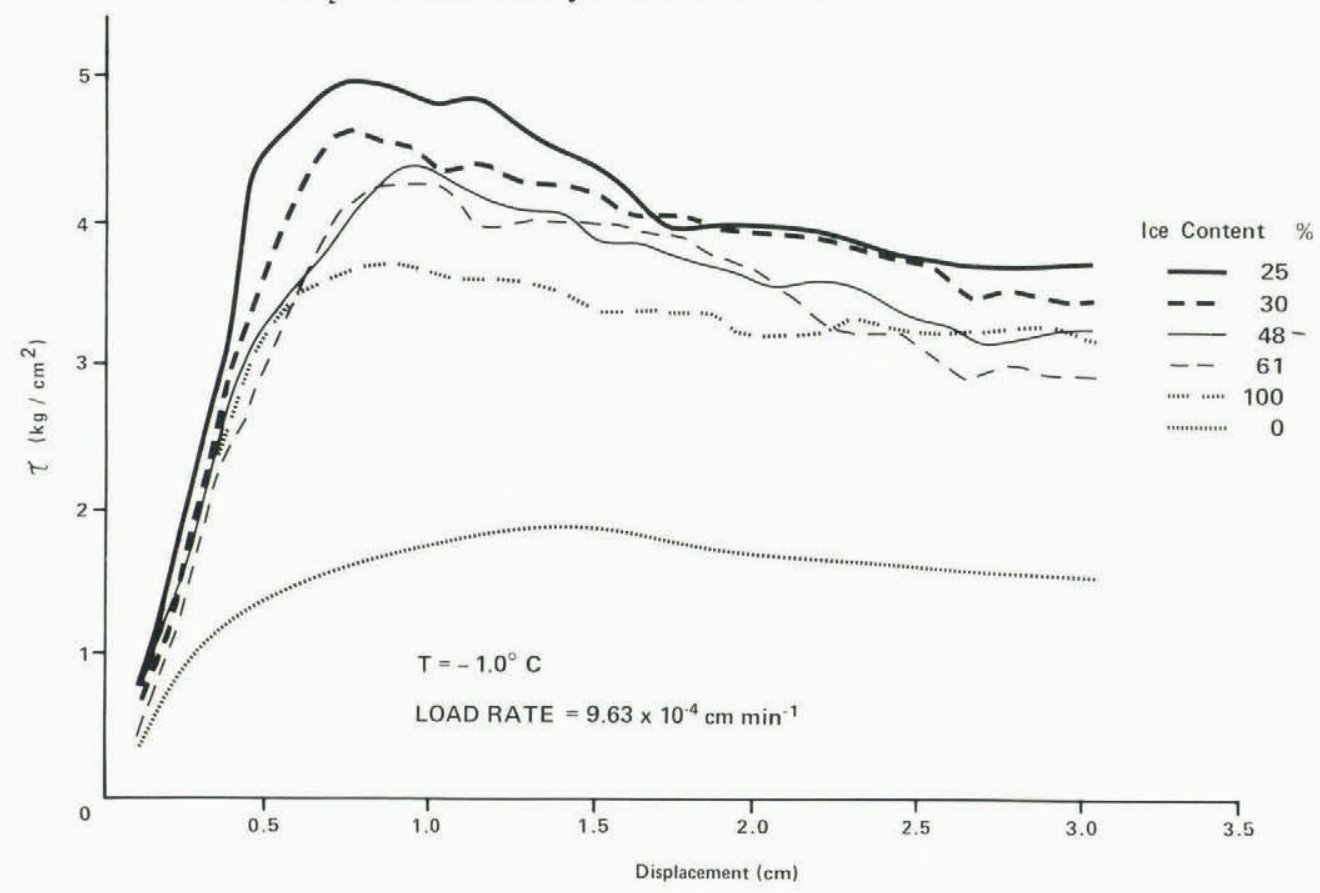

Fig. 6. Replicate stress-strain curves for varying ice contents carried out on bulk sample II.

parison, the $25 \%$ ice content samples reached peak strength at $0.9 \mathrm{~cm}$ of displacement while the polycrystalline ice reached peak at $0.6 \mathrm{~cm}$ of displacement (Table II). The greatest difference between $\tau_{p}$ and $\tau_{r}(35 \%)$ as indicated by the $\tau_{r} / \tau_{p}$ ratio is found in the $25 \%$ ice content samples. The polycrystalline ice samples display a residual strength which is approximately $15 \%$ less than the peak. Samples of all other ice contents have ratios ranging from 0.72 to 0.79 (Table II).
In Figure 6 the results of a series of shear tests on Sample II with increasing ice content but the same normal load are shown. This figure clearly indicates the effect of ice content on peak shear strength. The sample providing the least resistance to shear (and thus, displaying the lowest peak and residual

strengths) had a $0 \%$ ice content. The sample providing the greatest resistance to shear had a $25 \%$ ice content. As the ice content of the samples increased beyond $25 \%$, the peak shear strength of the-matrix de- 
creased. While the pure polycrystalline ice provided less resistance to shear than the saturated samples, it was 1.5 to 2.5 times stronger than the frozen dry samples (Fig. 6).

\section{Mohr-Coulomb failure envelopes}

Failure envelopes for the test samples are shown in Figure 7 . The data points of the $0 \%$ ice content samples can be fitted by the standard linear MohrCoulomb equation (Equation (1)). The cohesion constant $\left(0.39 \mathrm{kgf} / \mathrm{cm}^{2}\right)$ for the $0 \%$ ice content sample is considerably lower than the cohesion constants $(\sqrt{c})$ for the frozen saturated and supersaturated samples

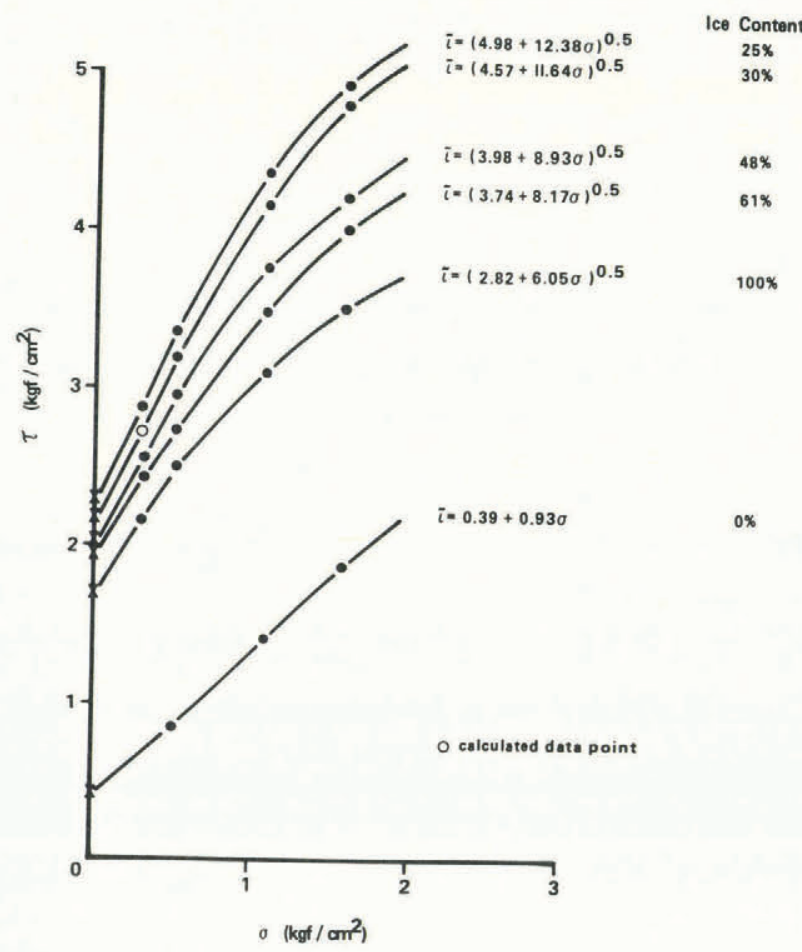

Fig. 7. Failure envelopes of the frozen samples.

(1.94 to $\left.2.23 \mathrm{kgf} / \mathrm{cm}^{2}\right)$ and the polycrystalline ice $1.68 \mathrm{kgf} / \mathrm{cm}^{2}$ ) indicating the limited significance of the small amount of ice in the frozen dry samples.

At ice contents greater than $25 \%$ the data show a distinct curvilinearity which is typical of frozen soils (Sayles, 1973). Although several general equations can be fitted to the data they are best fitted by

$$
\tau=\left(c+b_{n}\right)^{0.5}
$$

where $\sqrt{c}$ is the cohesive force at zero normal load and $b$ is a function of internal friction $(\phi)$. This is in agreement with Ladanyi (1972), who argues that the failure envelopes of frozen soils generally have a parabolic shape.

In general the data of Figure 7 represent a family of curves that show a decrease in cohesion and rate of change of peak shear strength with increasing ice content above $25 \%$. This is characterized by the coefficients $b$ and $c$ of the failure-envelope equations (Fig. 7 ).

As the ice content of the matrix increases from 0 to $25 \%$ by volume, the cohesion constant increases significantly. Above sample saturation (approximately $25 \%$ ) it was found that the coefficient $c$ decreases as an exponential function of ice content. At $100 \%$ ice content (pure ice) the constant lies between that of an ice-free and ice-saturated sample (25\% ice content). Similarly, the b coefficients, which are an indirect measure of internal friction, also decrease as an exponential function of ice content.

\section{DISCUSSION}

\section{Stress-strain curves}

The strength of frozen soils is primarily derived from cohesion resulting from ice-to-ice or ice-to-rock contacts. At temperatures above $-1.0^{\circ} \mathrm{C}$, ice crystal boundaries become non-rigid ( 1 imited cohesion) and sliding is the dominant response to shear stress. In systems with a high ice concentration, shear stresses are transferred easily from one crystal to another. However, as the concentration of mineral grains increases, the shear strength due to the cohesive effects of the ice is supplemented or substituted by a rock-to-rock frictional component since individual particles come into contact with one another (Tsytovich, 1973). This transition is indicated by the stress-strain curves for the frozen and polycrystalline ice samples (Figs 4 and 5 ).

The shear tests on pure polycrystalline ice (Fig. 4) produced relatively smooth stress-strain curves which are similar to the findings of Gold (1970). However, at 1 ower ice contents (e.g. $48 \%$ and $61 \%$ ice content curves, Figs $5 a$ and 6 ) the curves are somewhat irregular and display one or more "penultimate" peak strengths followed by the "ultimate" or true peak strength. Ir regular stress-strain curves of many frozen soils have shown this characteristic (e.g. Chamberlain and others, 1972; Sayles, 1973) but in general are somewhat less spiked, which most probably results from the finer texture of the sediments used in most other studies.

Ir regular peaks below the true peak strength of the sample result from the random interlocking of coarse particles. When two or more coarse grains interlock, especially across the potential shear plane, shearing is impeded and stresses build up until one or more of the particles fail (by fracturing or crushing) or are forced to slide or roll around one another causing dilation. When this occurs excess shear stresses are relieved and sample strength is quickly reduced.

Although the above suggests that samples with lower ice content are subject to significantly more interlocking than samples with higher ice content, the stress-strain curves of the samples with $25 \%$ and $30 \%$ ice content (Fig. $5 \mathrm{a}$ and b) appear much more regular than those of the samples with the higher ice content. In the cases with lower ice content, particle interlocking is less of a random occurrence and the effect of individual particles interlocking is less obvious, resulting in somewhat more regular stress-strain curves.

\section{Mohr-Coulomb failure envelopes}

The curvilinear failure envelopes for the frozen samples also indicate the importance of ice content on peak shear strength. At low normal stresses, pore ice, although significantly increasing cohesion, separates the particles reducing the internal friction $(\phi)$ of the sample. This is indicated by the slight bending down of the failure envelope which would normally remain relatively constant on a dry unfrozen sample ( $F$ ig. 7 ).

As the normal stress increases, pressure-melting is enhanced thereby reducing the rate at which shear resistance increases. In addition, ice-filled voids limit dilatation at the higher normal stresses increasing particle fracture and crushing. In general, lower shear stresses are required to produce crushing and fracturing than those needed for dilatation in this situation. Both factors (pressure-melting and limited dilatation) cause a further bending down of the failure envelope at the higher normal stresses where under other circumstances it would remain constant.

The two components of sample strength (cohesive force and internal friction) collectively generate 


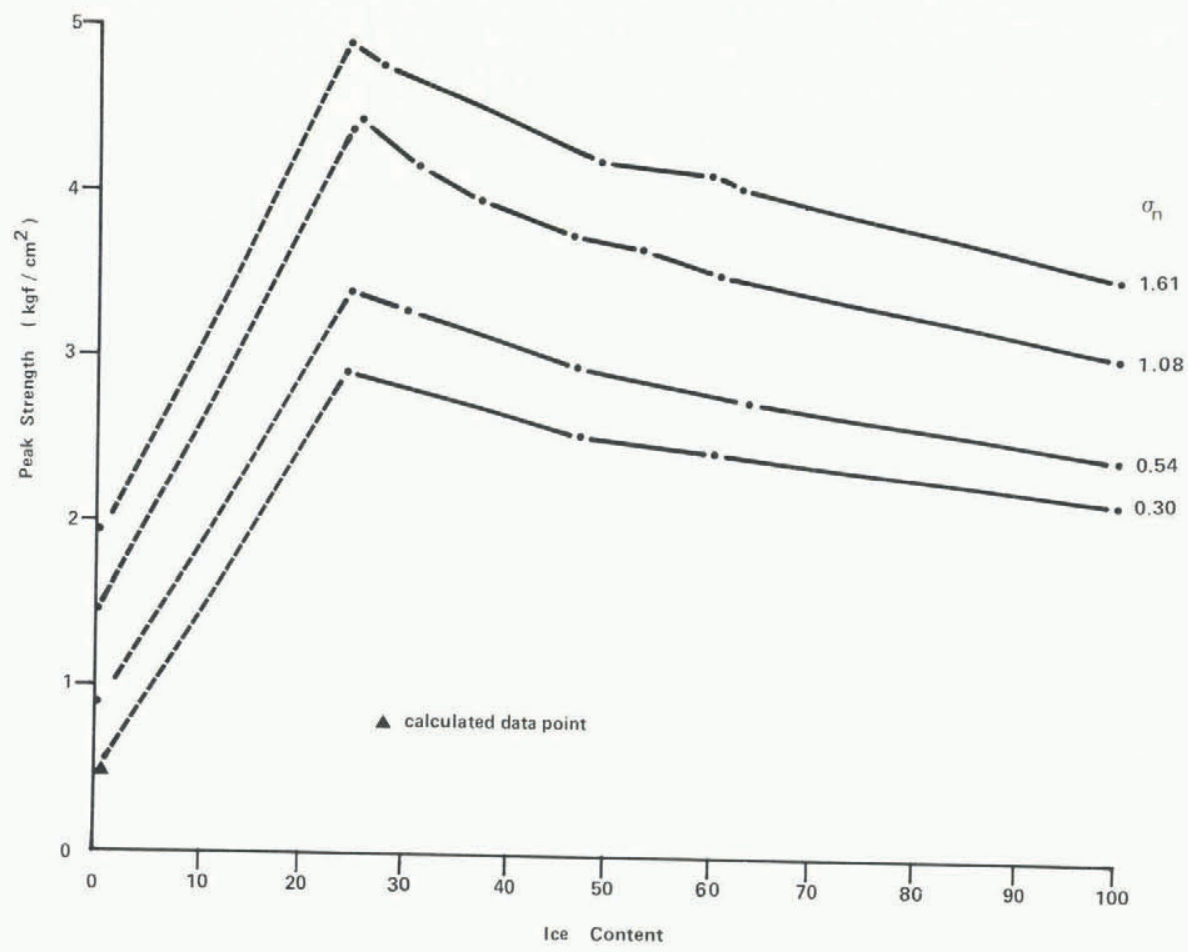

Fig. 8. Variation of peak shear strength with ice content.

the peak shear strength of a particular sample. However, peak strength is also significantly affected by ice content because of its direct influence on these two components. As indicated in Figure 8 peak shear strength appears to increase dramatically from $0 \%$ ice content to saturation ( $25 \%$ ice content) and then decreases as ice content approached $100 \%$. Although tests were not conducted on samples with ice contents between $0 \%$ and $25 \%$ (saturated) rapid increases in strength with increasing ice content up to saturation have been noted by Baker (1979) and Tsytovich (1973) for fine-grained soils. Moreover, decreases in strength with increasing ice content above saturation for well-sorted frozen sands have also been reported by Goughnour and Andersland (1968) and by Tsytovich (1973).

The sharp initial increase in peak strength results from increased cohesive forces produced by pore ice which effectively cement together individual particles. As a result of these ice-cementation bonds dilatation is impeded thereby increasing shear resistance in a manner similar to increasing normal stress. At sample saturation maximum strength is derived from the combined effects of ice cementation bonds, internal friction, and normal stress (Goughnour and Andersland, 1968).

As the ice content is increased above saturation pore ice begins to dominate the sample and peak strength is reduced. Initially only a few particles will be pushed out of contact reducing internal friction. However, since cohesion during dilatation is primarily a function of ice cement bonds, and not the cohesivenesss of ice itself, an increase in volumetric ice content causes an initial sharp decrease in ice cement bonds and hence sample strength (Babcock and others, 1978).

Goughnour and Andersland (1968) suggest that as ice content increases above saturation, a critical point is reached when almost all grains are out of contact with one another. As a result, the shear strength of the sample becomes almost totally dependent on the strength of the ice rather than the internal friction of the soil particles. This point is indicated by a sharp inflection on the peak strength/ ice-content curve presented by Goughnour and Andersland (1968).

Their data, for well-graded sand, plot as a bilinear curve with the intersection of the straight segments representing a critical ice content of approximately $58 \%$. Although data are 1 imited, no inflection point is readily apparent in any of the peak strength/ice content curves for the frozen rockglacier matrix debris used in the present study. Rather the data plot as relatively smooth power funtions of the form

$$
\tau=\mathrm{a} 0^{\beta}
$$

where $C$ is ice content by volume and $\tau$ is peak shear strength $\left(\mathrm{kgf} / \mathrm{cm}^{2}\right)$ ( $\left.\mathrm{Fig.} 9\right)$.

In well-mixed samples with a limited range of grain-sizes, such as those used by Goughnour and Andersland (1968), there will be a discrete point when virtually all the particles are placed out of contact by ice because of the relatively uniform packing arrangement of the particles. Conversely in more heterogeneous material ( $i . e$. rock-glacier debris) there will be a gradual reduction in the solid-to-solid contacts because of the more random packing arrangements associated with poorly sorted samples.

Since test conditions for all samples were similar, one might expect a family of parallel curves separated by a distance proportional to the normal load. However, with consideration for the data limitations, there is a tendency for the slope coefficients $(B)$ of the regresion 1 ines to increase with increasing normal load up to $1.08 \mathrm{kgf} / \mathrm{cm}^{2}$. This is supported by the significant difference in the 0.3 and $1.08 \mathrm{kgf} / \mathrm{cm}^{2}$ normal load slope coefficients at $95 \%$ confidence level using a modified t-test (Table III). This apparent decrease in the slope coefficient with increasing normal load is thought to result from changes in sample dilatation, particle fracture, and pressure-melt.

At low normal loads, for a given ice content, sample dilatancy is only moderately impeded during the shearing process. As normal load increases, greater energy is required to unlock the rock particles and produce dilatation. This is particularly true of 


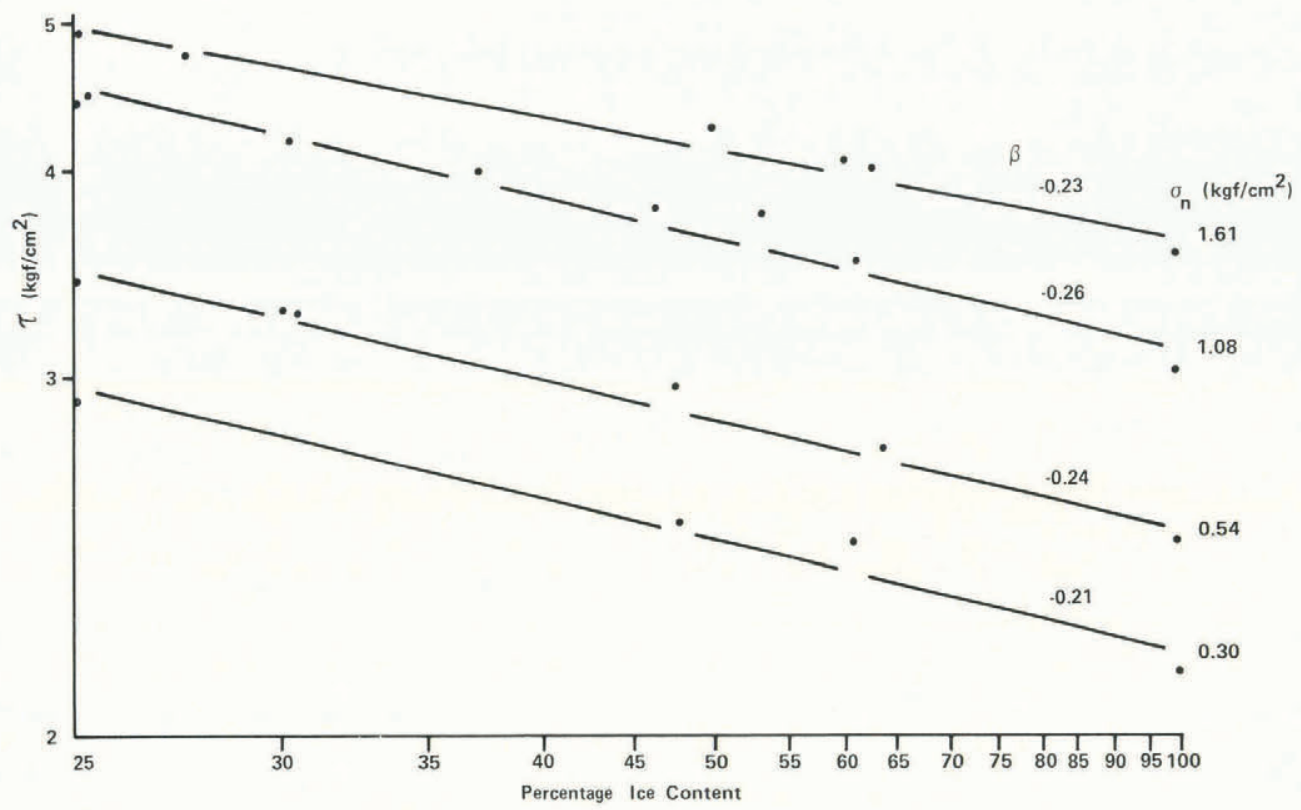

Fig. 9. Variation of peak shear strength with ice content of samples above saturation.

TABLE III. CALCULATED T-VALUES FOR THE COMPARISON OF SLOPE COEFFICIENTS $B$ FROM THE REGRESSIONS OF NORMAL LOAD AGAINST ICE CONTENT

\begin{tabular}{ccccc}
$\begin{array}{c}\text { Normal load } \\
\mathrm{kgf} / \mathrm{cm}^{2}\end{array}$ & 1.61 & 1.08 & 0.54 & 0.30 \\
\cline { 2 - 5 } 1.61 & $\mathrm{x}$ & & & \\
1.08 & -2.16 & $\mathrm{x}$ & & \\
0.54 & -0.69 & 1.85 & $\times$ & \\
0.30 & 0.82 & $3.16^{*}$ & 1.62 & $\times$
\end{tabular}

* significant at the $95 \%$ confidence limit.

samples with low ice contents which have a greater number of solid-to-solid contacts per unit volume. With increasing ice content, particles would become more separated by pore ice, decreasing internal friction and dilatation during shear. In addition higher normal stresses may also promote pressure-melting along the shear plane at solid-to-ice contacts which would reduce shear stresses. This process would be enhanced as ice content increased. Thus as normal load increases the slope of the peak strength/ice content curve should increase as suggested by the data presented in Figure 9.

When normal load reaches a critical level the energy required for dilatation may exceed the shear strength of individual particles. At this point the dilatation process may be replaced, at least in part, by particle fracturing and crushing which would be most significant at lower ice contents when particles are in closer juxtaposition. Since less energy is required to promote fracturing than to promote dilatation the negative slope of the peak strength/ice content curve may begin to decrease or remain

relatively constant above this critical normal load. This is suggested by the somewhat lower, but statistically insignificant (Table III), slope coefficient associated with the higher $1.61 \mathrm{kgf} / \mathrm{cm}^{2}$ normal load.

Boulton and others (1974) suggest from their work on subglacial tills that dilatation processes are almost el iminated when normal loads exceed a critical value. Above this value, shear strength remains essentially constant regardless of increasing normal load because sample strength is related more closely to the shear strength of the rock particles than the interlocking of the particles.

Based on the limited data presented in Figure 9, it is suggested that the critical dilatation value of the coarse frozen rock-glacier debris used in the present investigation is approximately $1.0 \mathrm{kgf} / \mathrm{cm}^{2}$. Although equipment limitations precluded testing at normal loads greater than $1.6 \mathrm{kgf} / \mathrm{cm}^{2}$ it is thought that for normal loads above this critical value, especially at lower ice contents, dilatation is impeded with shear strength becomning dependent on the fracturing and crushing of individual particles. In contrast, at lower normal loads (any ice content) or high ice content (any normal stress) particles may readjust to accommodate shearing resulting in the shear strength of the sample being more dependent on particle interlocking (internal friction) and dilatation processes.

\section{SUMMARY AND CONCLUSIONS}

Laboratory shear tests indicate that pore ice can significantly increase the strength of frozen coarse granular debris. Maximum strength is achieved with the sample at its minimum void ration and ice-saturated. As ice content increases above saturation, shear strength decreases because of the reduction in internal friction caused by the separation of individual particles by pore ice.

As normal load is increased, particle separation by pore ice and ice creep causes shear strength to increase less rapidly than in unfrozen samples producing a distinct parabolic failure envelope. The curvilinearity of the failure envelope is enhanced at higher normal loads because of particle fracture, pressure-melting at ice-rock contacts, and the suppression of particle dilatation during shear.

\section{ACKNOWLEDGEMENTS}

The authors wish to express their appreciation to B. Reynolds and M. Finoro for their assistance in modifying the shearbox and developing the dataacquisition instrumentation. Financial support (to 
W.G.N.) from the Natural Sciences and Engineering Research Council of Canada (Grant No. A0349) is gratefully acknowledged.

\section{REFERENCES}

Akroyd, T.N.W. 1957. Laboratory testing in soil engineering. London, Marshall Press.

Andersland, 0.B., and AlNouri, I. 1970. Timedependent strength behavior of frozen soils. Journal of the Soil Mechanics and Foundations Division, American Society of Civil Engineers, Vol. 96, No. SM4, p. 1249-65.

Babcock, E.A., and others. 1978. Shear phenomena in ice-thrust gravels, central Alberta, [by] E.A. Babcock, M.M. Fenton, and L.D. Andriashek. Canadian Journal of Earth Sciences, Vol. 15, No. 2, p. 277-81.

Baker, T.H.W. 1979. Strain rate effect on the compressive strength of frozen sand, Engineering Geology, Vol. 13, Nos. 1-4, p. 223-31.

Boulton, G.S., and others. 1974. Subglacial shearing and crushing, and the role of water pressures in tills from south-east Iceland, by G.S. Boulton, D.L. Dent, and E.M. Morris. Geografiska Annaler, Vol. 56A, Nos. $3-4$, p. $135-45$.

Carson, M.A., and Petley, D.J. 1970. The existence of threshold hillslopes in the denudation of the landscape. Institute of British Geographers. Transactions, Vol. 49, p. 71-95.

Chamberlain, E., and others. 1972. The mechanical behaviour of frozen earth materials under high pressure triaxial test conditions, [by] E. Chamberlain, C. Groves, and R. Perham. Géotechnique, Vol. 22, No. 3 , p. 469-83.

Gold, L.W. 1970. Processes of failure in ice. Canadian Geotechnical Journal, Vol. 7, No. 4, p. 405-13.

Goughnour, R.R., and Andersland, 0.B. 1968. Mechanical properties of a sand-ice system. Journal of the Soil Mechanics and Foundations Division, American Society of Civil Engineers, Vol. 94, No. SM4, p. 923-50.

Hobbs, P.V. 1974. Ice physics. Oxford, Clarendon Press. Johnson, P.G. 1978. Rock glacier types and their drainage systems. Grizzly Creek, Yukon Territory. Canadian Journal of Earth Sciences, Vol. 15, №. 9, p. 14961507.

Kavalak, L.J. Unpublished. Shear strength of some frozen coarse earth materials. [M.Sc. thesis, University of Guelph, 1980.]
Ladanyi, B. 1972. An engineering theory of creep of frozen soils. Canadian Geotechnical Journal, Vol. 9, No. 1 , p. 63-80.

McRoberts, E.C., and Morgenstern, N.R. 1973. A study of 1 andslides in the vicinity of the Mackenzie River, mile 205 to 660. Environmental-Social committee, Northern Pipelines. Task Force on Northern oil Development, Report 73-35.

Sayles, F.H. 1973. Triaxial and creep tests on frozen Ottawa sand. Permafrost. Second International conference, 13-28 July 1973, Yakutsk, U.S.S.R. North American contribution, p. 384-91.

Shusherina, E.P., and Bobkov, Yu.P. 1969. 0 vliyanii vlazhnosti merzlykh gruntov na ikh prochnost' [Effect of moisture content on frozen ground strength]. Merzlotnyye Issledovanyia, 9, p. 122-37. English translation: Canada. National Research Council. Technical Translation 1918, 1978.]

Tsytovich, N.A. 1973. Mekhanika merzlykh gruntov. Moscow, Vysshaya Shkola. [English translation: The mechanics of frozen ground. Edited by G.K. Swinzow. New York, McGraw-Hil1 Book Co., [C 1975$]$.]

Tsytovich, N.A., ed. 1959. Osnovy geokriologii (merzlotovedeniya). Chast' vtoraya. Inzhenernaya geokriologiya [Principles of geocryology (permafrost studies). Part two. Engineering geocryology]. Moscow, Izdatel'stvo Akademi i Nauk SSSR. [English translation of p. 28-79 published as: Canada. National Research Council, Technical Transiation 1239, 1966.]

Vyalov, S.S., and others. 1962. Prochnost' $i$ polauchest' merzlykh gruntov $i$ raschety ledogruntovykh ograzhdenii [The strength and creep of frozen soils and calculations for ice-soil retaining structures]. [By] S.S. Vyalov [and 6 others]. Moscow, Izdatel'stvo Akademi i Nauk SSSR. [English transiation: U.S. Cold Regions Research and Engineering Laboratory. TransLation 76, 1965.]

Vyalov, S.S., and others. 1966. Metodika opredeleniya kharakteristik polzuchesti, dlitel'noi prochnosti, $i$ szhimayemosti merzlykh gruntov [Methods of determining creep, long-term strength, and compressibility characteristics of frozen soils]. [By] S.S. Vyalov, S.E. Gorodetskiy, V.F. Yermakov, A.G. Zatsarnaya, N.K. Pekarskaya. Moscow, Izdatel 'stvo "Nauka". [English translation: Canada. National Research Council. Technical Translation 1364, 1969.]

Whalley, W.B. 1974. Rock glaciers and their formation as part of a glacier debris-transport system. University of Reading. Dept. of Geography. Geographical Papers, NNo. 24. 